\title{
A new cycle of jökulhlaups at Russell Glacier, Kangerlussuaq, West Greenland
}

\author{
Andrew J. RUSSELL, ${ }^{1}$ Jonathan L. CARRIVICK, ${ }^{2}$ Thomas INGEMAN-NIELSEN, ${ }^{3}$ \\ Jacob C. YDE, ${ }^{4,5}$ Meredith WILLIAMS ${ }^{6 *}$ \\ ${ }^{1}$ School of Geography, Politics and Sociology, Newcastle University, Newcastle-upon-Tyne NE1 7RU, UK \\ E-mail: Andy.Russell@ncl.ac.uk \\ ${ }^{2}$ School of Geography, University of Leeds, Leeds LS2 9JT, UK \\ ${ }^{3}$ Arctic Technology Centre, Technical University of Denmark, Kemitorvet B-204, DK-2800 Lyngby, Denmark \\ ${ }^{4}$ Center for Geomicrobiology, University of Aarhus, Ny Munkegade, B-1540, DK-8000 Aarhus, Denmark \\ ${ }^{5}$ Bjerknes Centre for Climate Research, University of Bergen, Allegaten 70, NO-5007 Bergen, Norway \\ ${ }^{6}$ School of Civil Engineering and Geosciences, Newcastle University, Newcastle upon Tyne NE1 7RU, UK
}

\begin{abstract}
Jökulhlaups in 2007 and 2008 from an ice-dammed lake at the northern margin of Russell Glacier, West Greenland, marked the onset of a renewed jökulhlaup cycle after 20 years of stability. We present a record of successive ice-dammed lake drainage events and associated ice-margin dynamics spanning $\sim 25$ years. Robust calculations of lake volumes and peak discharges are made, based on intensive field surveys and utilizing high-spatial-resolution orthophotographs of the lake basin and ice margin. These data enable identification of controls on the behaviour of the ice-dammed lake and provide the first field-based examination of controls on jökulhlaup magnitude and frequency for this system. We find that Russell Glacier jökulhlaups have a much higher peak discharge than predicted by the Clague-Mathews relationship, which we attribute to an unusually short englacial/subglacial routeway and the presence of a thin ice dam that permits incomplete sealing of jökulhlaup conduits between lake drainage events. Additionally, we demonstrate that the passage of jökulhlaups through an interlinked system of proglacial bedrock basins produces significant attenuation of peak discharge downstream. We highlight that improved understanding of jökulhlaup dynamics requires accurate information about ice-dammed lake volume and ice-proximal jökulhlaup discharge.
\end{abstract}

\section{INTRODUCTION AND AIMS}

Glacier-dammed lakes exist in many parts of the world and often pose an extreme hazard when they drain rapidly, generating jökulhlaups (glacial outburst floods). Glacier margin recession from tributary valleys has resulted in the formation of new ice-dammed lakes and the destabilization of existing ice-dammed lakes through lowering and weakening of ice dams. Increases in meltwater production have resulted in the formation and destabilization of many icedammed lakes (e.g. Wiles and others, 2008). While controls on ice-dammed lakes have been described from intensive field campaigns (e.g. Walder and others, 2006; Huss and others, 2007), detailed investigations of cycles of repeated draining of a single ice-dammed lake are quite rare (e.g. Mathews and Clague, 1993; Roberts and others, 2005; Ng and others, 2007; Ng and Liu, 2009). In Greenland, a number of ice-dammed lakes are known to drain periodically (e.g. Helk, 1966; Higgins, 1970; Dawson, 1983; Clement, 1984; Mayer and Schuler, 2005), but little is known about the controls on these long-term drainage cycles.

The ice-dammed lake on the northern flank of Russell Glacier (Fig. 1) drained in July 1987 (Russell and de Jong, 1988; Russell, 1989, 1993c), marking the termination of a cycle of at least eight jökulhlaups, identified from sediment;ary evidence within the proglacial jökulhlaup channel (Russell, 2009). The first evidence of jökulhlaups from this ice-dammed lake is provided by major proglacial channel

*Present address: School of Science, University of Greenwich at Medway, Central Avenue, Chatham Maritime, Kent ME4 4TB, UK. morphological change, identified from aerial photographs taken in 1944 and 1953 (Russell, 1993a). A jökulhlaup on 31 August 2007 marked renewed ice-dammed lake drainage after 20 years of stability (Mernild and others, 2008; Česnulevičius and others, 2009; Mernild and Hasholt, 2009). A subsequent jökulhlaup on 31 August 2008 demonstrated that the 2007 jökulhlaup indeed marked the onset of a new cycle.

The onset of a new jökulhlaup cycle at Russell Glacier is important because ice-dammed lake level, extent and stability are known to fluctuate in response to climatedriven fluctuations of ice thickness and glacier margin position (Thórarinsson, 1939; Evans and Clague, 1994; Anderson and others, 2003). However, most knowledge of ice-dammed lake drainage processes is derived from the analysis of lakes impounded by glaciers that have undergone progressive retreat since the Little Ice Age (e.g. Clague and Mathews, 1973; Desloges and others, 1989; Walder and Costa, 1996; Ng and Björnsson, 2003; Ng and others, 2007). Evans and Clague (1994) presented a model of the 'jökulhlaup cycle' where glacier recession, accompanied by reduction in ice-dammed lake volume, generates a cycle of jökulhlaups of progressively decreasing magnitude.

We present an examination of the characteristics of, and controls on, the behaviour of an unnamed ice-dammed lake at Russell Glacier, near Kangerlussuaq, West Greenland. To do this we (1) reconstruct the volume and peak discharge of the 2007 and 2008 jökulhlaups from Russell Glacier, (2) recalculate the volume and peak discharge of jökulhlaups in 1984 and 1987 from the same ice-dammed lake utilizing new data and (3) evaluate controls on the jökulhlaup cyclicity at Russell Glacier. 


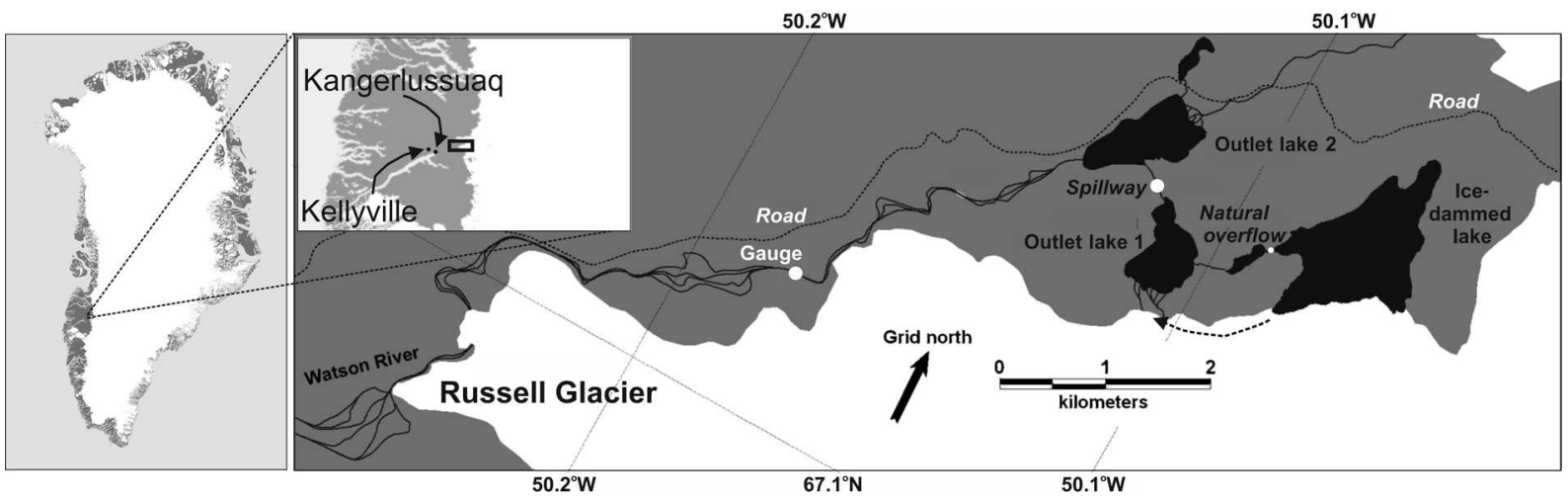

Fig. 1. Location of field area within Greenland and in relation to the Kangerlussuaq and Kellyville GPS site (KELY). The ice-dammed lake, outlet lake $1(\mathrm{OL} 1)$ and outlet lake $2(\mathrm{OL} 2)$ are shown in relation to the northern margin of Russell Glacier. The ice-dammed lake drains through an englacial/subglacial tunnel, indicated by a dashed arrow, for a distance of $\sim 1 \mathrm{~km}$, routing jökulhlaups into OL1. Proglacial jökulhlaup peak discharge reconstructions were undertaken at the spillway between OL1 and OL2 and at the 1987 gauged reach (labelled 'Gauge').

\section{STUDY AREA AND METHODS}

Russell Glacier is an outlet glacier on the western margin of the Greenland ice sheet, located $35 \mathrm{~km}$ east of Kangerlussuaq (Søndre Strømfjord) (Fig. 1). The Russell Glacier meltwater catchment has an area of $\sim 90 \mathrm{~km}^{2}$ (Van de Wal and Russell, 1994), with summer ablation controlled discharges of up to $70 \mathrm{~m}^{3} \mathrm{~s}^{-1}$ (Russell, 1989; Van de Wal and Russell, 1994; Russell and others, 1995). Within the Kangerlussuaq meltwater catchment, of which the Russell Glacier meltwater catchment is part, jökulhlaups have originated from the draining of ice-marginal lakes (Russell and others, 1990), supraglacial lakes (Russell, 1990, 1993c) and ice-debris-dammed lakes (Russell and others, 1995). Repeated jökulhlaups from the largest ice-marginal icedammed lake at the northern margin of Russell Glacier are relatively well documented (e.g. Sugden and others, 1985; Gordon, 1986; Russell and de Jong, 1988; Scholz and others, 1988; Russell, 1989, 1993b, 2007, 2009; Russell and Marren, 1999). The 1984, 1987, 2007 and 2008 jökulhlaups all routed through a $1 \mathrm{~km}$ long subglacial/englacial tunnel at the southwestern corner of the ice-dammed lake (Figs 2 and $3 \mathrm{a}$ and $\mathrm{b}$ ) before flowing out across a coarse-grained delta into outlet lake 1 (OL1) (Figs 1 and 2) (Russell, 1989, 2007; Russell and Marren, 1999). Jökulhlaups drain from OL1 northwards into outlet lake 2 (OL2) via a bedrock spillway whose cross-sectional shape controls the level of the upper lake (Figs 1 and 2) (Russell, 2007). On exiting OL2, jökulhlaups flow through a series of bedrock-confined channels and outwash plains before flowing west along the glacier snout (Fig. 1).

Fieldwork conducted in October 2007 and February 2008 comprised bathymetric surveying of the ice-dammed lake (Fig 3c and d) using a Trimble 4600 LS singlefrequency, differential global positioning system (dGPS) with a stated accuracy $\pm 20 \mathrm{~cm}$ in real-time kinematic (RTK) mode. Fieldwork conducted in May 2008 included precision surveying of the ice-dammed lake level, proglacial lake water surface and wash limit levels, and proglacial jökulhlaup channel cross-sectional areas. This May 2008 fieldwork was carefully timed to obtain data on the 2007 jökulhlaup lake level and 2007 jökulhlaup wash limits while the evidence was still intact. Maximum jökulhlaup water levels were determined from wash limits that comprised erosional trimlines, trash lines of shrub twigs and leaves, silt cover on vegetation and the upper extent of ice block meltout deposits (e.g. Carrivick and Rushmer, 2009). All positions and heights surveyed in May 2008 were obtained using a Leica GPS500 dGPS used in RTK mode with occupation of temporary base stations. Base stations were precisely located by post-processing relative to continuous dGPS data for Kellyville 'KELY' GPS station, $45 \mathrm{~km}$ away. Our surveyed points (Fig. 3c) have a mean threedimensional error of $<10 \mathrm{~cm}$ (commonly $<1 \mathrm{~cm}$ ) which
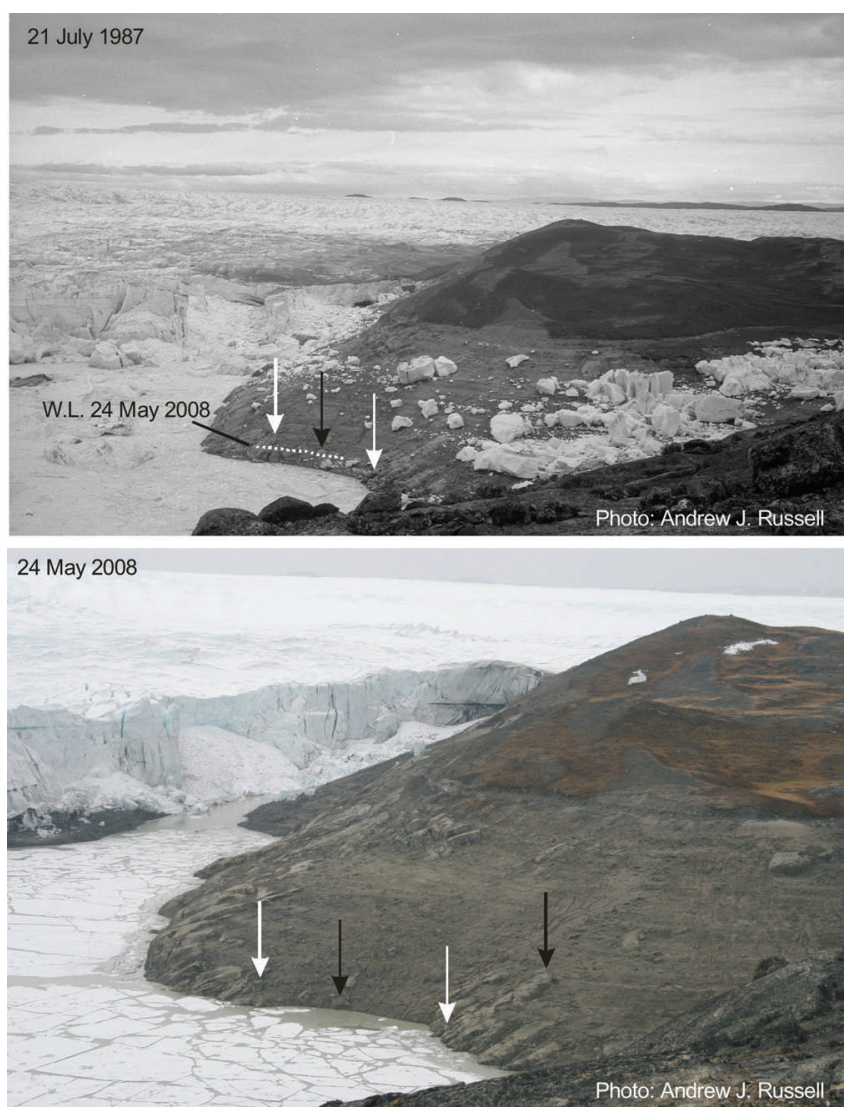

Fig. 2. Ice-dammed lake at the northern margin of Russell Glacier, on 21 July 1987 and 24 May 2008. Both photographs were taken immediately after a jökulhlaup, permitting comparison between the lake level drops. Arrows indicate common points, and are used for examining ice-margin position and thickness. 

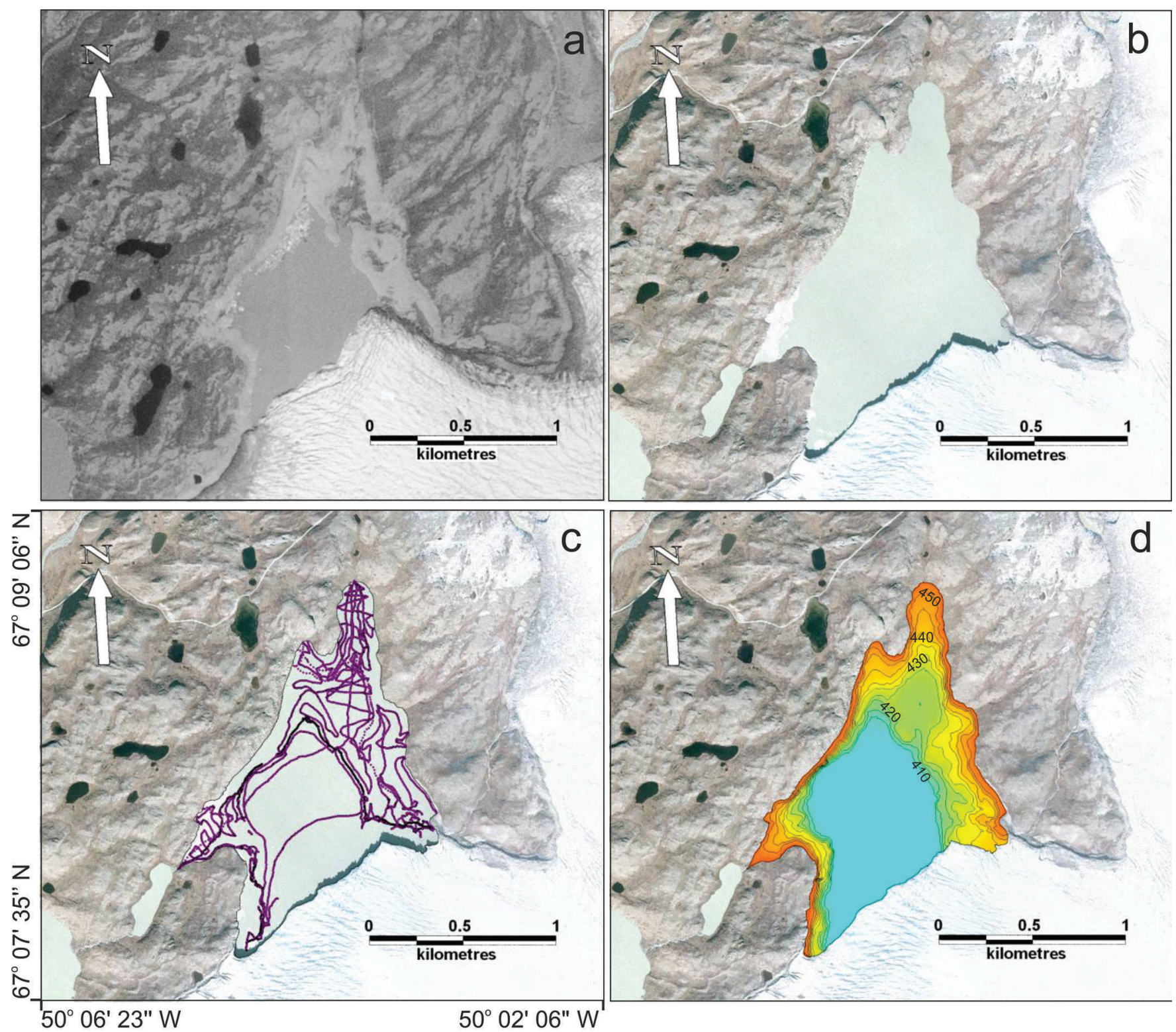

Fig. 3. Recent visual history of ice-dammed lake dynamics. (a) 1985 aerial photograph by Danish National Survey and Cadastre shows low lake level, smaller lake surface area and thinner ice. (b) 2006 aerial photograph by ARTEK shows maximum lake level, larger lake volume and thicker ice. Maximum lake level is controlled by a proglacial bedrock spillway which drains into OL1. (c) Tracks of a kinematic dGPS survey undertaken in February 2008 to interpolate lake basin bathymetry. (d) Lake bathymetric model with contours at $5 \mathrm{~m}$ intervals. Maximum lake level illustrated is $453.7 \mathrm{~m}$. Lake levels were measured in May 2008.

makes our measurements comparable in accuracy to those of previous surveys (e.g. Russell, 1989). The relative accuracy of the Trimble and Leica dGPS locations was assessed from points common to both datasets; these points are within $0.5 \mathrm{~m}$ of each other, and the mean elevation difference is $0.211 \mathrm{~m}$.

Peak discharge was reconstructed using three techniques: (1) Walder and Costa's (1996) empirical relationship utilizing ice-dammed lake volume, (2) the slope/area technique at three stable proglacial channel cross sections and (3) a spillway equation used to reconstruct flow exiting OL1 over a bedrock lip.

Walder and Costa (1996) present an empirical power-law relationship between maximum jökulhlaup discharge, $Q_{\max }$ and volume of water drained, $V$, for a dataset of 26 icedammed lakes which drain subglacially. The Walder and Costa relationship, which builds on the Clague-Mathews relationship, was used to estimate jökulhlaup peak discharge from ice-dammed lake volume (Clague and Mathews, 1973; $\mathrm{Ng}$ and Björnsson, 2003):

$$
Q_{\max }=46 V^{0.66} \text {. }
$$

The slope/area technique was used to reconstruct peak flood discharge within proglacial jökulhlaup channels. The bedrock spillway between OL1 and OL2 provides a stable channel cross-sectional geometry, confirmed by pre- and post-2007 channel cross-sectional surveys and observations. Reconstructions downstream of OL2 were made at a stable reach used to gauge the 1987 jökulhlaup (Russell, 1989, 1993b, 2009; Russell and Marren, 1999). The peak discharge of the 1987 jökulhlaup was reconstructed for comparison with discharge measured directly during that event (Russell, 1989), providing validation of the hydraulic techniques used. 
Mean flow velocities for each channel cross section were calculated using three variants of the standard Manning resistance equation, as well as an adaptation of the Keulegan equation (Thompson and Campbell, 1979; Russell and others, 1999, 2007; Carrivick and others, 2004; Carrivick, 2007a). The Manning and Keulegan resistance equations require the input data: (1) energy gradient or water surface slope, (2) channel hydraulic radius and (3) grain roughness (Chow, 1959; Henderson, 1966; Maizels, 1983). Four methods were used to characterize grain and form roughness in order to identify potential problems of incorporating the channel resistance. Water surface slope was derived from observed water surfaces and well-defined wash limits for the 1987 and 2007 jökulhlaups, respectively. Channel hydraulic radius was calculated from cross-sectional areas and wetted perimeters derived from surveyed channel cross sections. Channel roughness was characterized by the DarcyWeisbach friction factor, $f$, and Manning's $n$. The modified Keulegan equation proposed by Thompson and Campbell (1979), being the least empirical and least site-specific, was used to calculate $f$ in the Darcy-Weisbach equation (Church and others, 1990). The Darcy-Weisbach equation was used to obtain mean velocity, $v$ :

$$
v=\sqrt{\frac{8 g d s}{f}}
$$

where $g$ is the acceleration due to gravity $\left(9.81 \mathrm{~m} \mathrm{~s}^{-2}\right), d$ is the flow depth $(\mathrm{m}), s$ is the slope and $f$ is calculated using Thompson and Campbell's (1979) equation:

$$
\frac{1}{\sqrt{f}}=\left(1-0.1 \frac{k_{\mathrm{s}}}{R}\right) 2 \log _{10}\left(\frac{12 R}{k_{\mathrm{s}}}\right),
$$

where $R$ is the hydraulic radius $(\mathrm{m})$ and $k_{\mathrm{s}}$ is the size of the roughness elements, equal to 4.5 times the clast size, $D_{i}$. In this case, we calculated $k_{\mathrm{s}}$ as the proportion of the flow depth, $d$, occupied by flow resistance elements, $\Delta A$ :

$$
k_{\mathrm{s}}=4.5 d \Delta A \text {. }
$$

The proportion of the flow depth occupied by flow resistance elements, $\Delta A$, consisting of boulders, was estimated visually and expressed as a percentage. A single $f$ value was calculated for each cross section. Calculated $f$ values were converted to Manning's $n$ using an equation presented by Richards (1982):

$$
n=\sqrt{\frac{f R^{\frac{1}{3}}}{8 g}} .
$$

Manning's $n$ roughness values were firstly calculated from grain-size characteristics using the Manning-Limerinos and Manning-Strickler equations:

$$
\begin{gathered}
n=0.038 D_{90}^{1 / 6}, \\
\frac{n}{d^{1 / 6}}=\frac{0.113}{1.16+2.0 \log _{10} \frac{d}{D_{84}}},
\end{gathered}
$$

where $D_{84}$ and $D_{90}$ are the 84th and 90th percentile grainsize values, respectively. $D_{84}$ and $D_{90}$ percentiles were derived for each cross section from visual estimates of surface grain sizes (Maizels, 1983; Ryder and Church, 1986; Russell, 1994). Secondly, and for comparison with $n$ values from observations of grain roughness, $n$ values were also calculated solely from water surface slope and the hydraulic radius, i.e. from form roughness, using Jarrett's
(1984) equation:

$$
n=0.32 S^{0.38} R^{-0.16}
$$

where $S$ is the downstream water surface gradient.

Overall, mean flow velocities were derived for each proglacial channel cross section using each of the four variants of the slope/area technique presented above. Peak flood discharges were derived by multiplying mean flow velocities by channel cross-sectional areas.

Instantaneous outflow discharge, $Q_{w}\left(\mathrm{~m}^{3} \mathrm{~s}^{-1}\right)$, from the maximum level of OL1 was calculated using the spillway equation (Featherstone and Nalluri, 1982):

$$
Q_{w}=\left(\frac{A^{3} g}{b}\right)^{0.5},
$$

where $A$ is the cross-sectional area of the spillway $\left(\mathrm{m}^{2}\right)$ and $b$ is water surface width $(\mathrm{m})$.

\section{RESULTS}

\section{Ice-dammed lake volume: 1984-2008}

Draining of the ice-dammed lake on the northern margin of Russell Glacier occurred on 31 August 2007 and lasted for 17 hours (Mernild and others, 2008; Česnulevičius and others, 2009; Mernild and Hasholt, 2009) (Fig. 2). Our direct measurements of the ice-dammed lake basin in October 2007 show that the lake did not drain completely, but that the water level lowered by $49.2 \pm 0.2 \mathrm{~m}$ (Table 1 ). This lowering differs significantly from Mernild and others' (2008) estimate of $\sim 25 \mathrm{~m}$ and also from Česnulevičius and others' (2009) value of $55 \mathrm{~m}$. Our measured lake volume drained during the 2007 jökulhlaup was $(39.1 \pm 0.8) \times 10^{6}$ $\mathrm{m}^{3}$ (Table 1). This volume is far greater than published values of $11.3 \times 10^{6} \mathrm{~m}^{3}$ (Mernild and others, 2008; Mernild and Hasholt, 2009) and $20.9 \times 10^{6} \mathrm{~m}^{3}$ (Česnulevičius and others, 2009). Mernild and others (2008) tenuously ascribed a further $17.5 \times 10^{6} \mathrm{~m}^{3}$ of water as arising from 'frictional melting of ice as the flood travelled in contact with the glacier together with an input from base flow'.

Between 1985 and 2006, glacier surface elevation in the vicinity of the ice-dammed lake increased by $\sim 22 \pm 5 \mathrm{~m}$ (Fig. 3a and b). As the most recent pre-jökulhlaup orthophotograph dates from 2006, these estimates of glacier surface elevation are based on comparisons of oblique field photographs and corresponding natural markers in the field such as lateral moraines, ice-marginal ponds and boulders (Fig. 2). Besides an ice thickness change, an ice-margin advance between 1985 and 2006 is evidenced by field observations of a newly formed push moraine within the icedammed lake basin and along the remainder of the local ice margin. While Russell Glacier is known to have advanced between 1968 and 1999 (Knight and others, 2000), it is interesting to note that the extent of the glacier in the icedammed lake basin decreased by 100-180 m between 1985 and 2006 (Fig. 3a and b). In the months immediately following the 2007 draining, we observed that the margin of Russell Glacier advanced $\sim 50 \mathrm{~m}$ into the lake basin. However, no change in ice-margin position was observed following the August 2008 lake draining. The position of the ice margin is important because it controls the relationship between ice-dammed lake level and volume (Fig. 4). Because of ice-margin fluctuations, ice-dammed lake volume for the maximum lake level increased by $8 \times 10^{6} \mathrm{~m}^{3}$ from 1985 to 2006 (Fig. 4). 

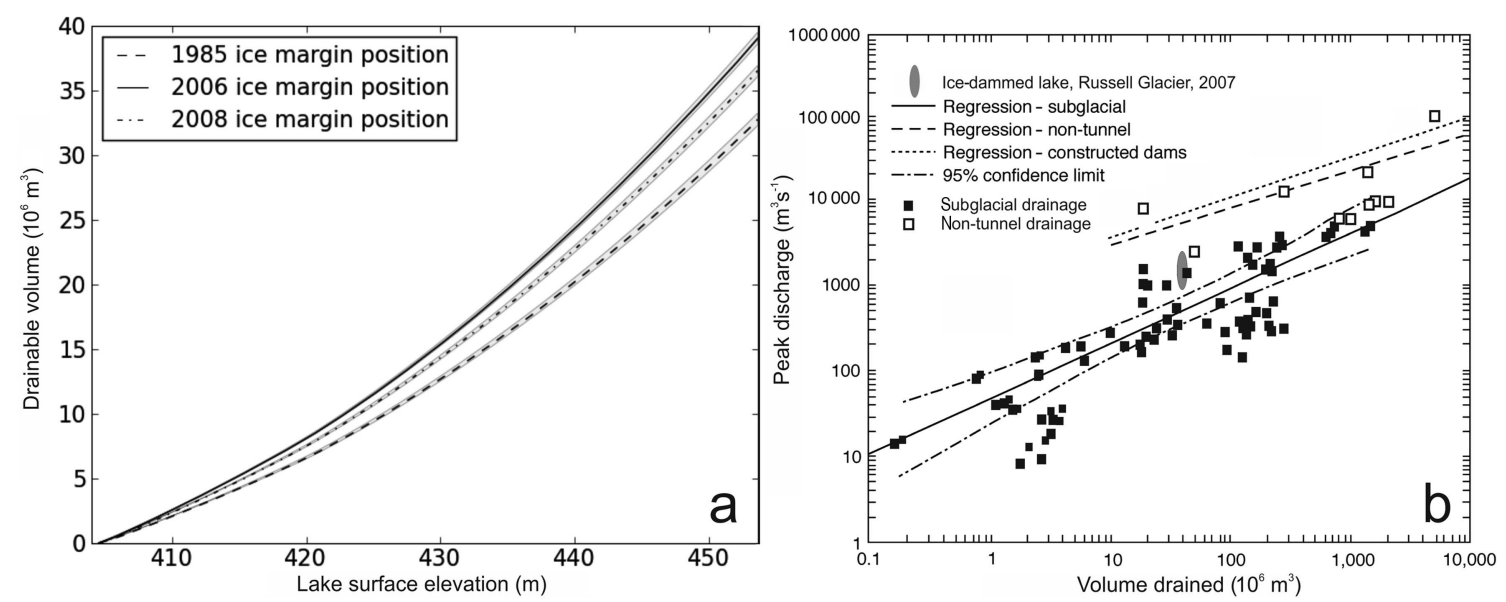

Fig. 4. (a) Stage/volume graph for the ice-dammed lake. The three curves show the stage/volume relationships based on the changes in icemargin position. The 1985 and 2006 curves are based on digitized ice-margin positions from air photographs, and the 2008 curve is based on GPS measurements. The grey zones indicate changes in drainable volume based on a $10 \mathrm{~m}$ advance or retreat of the glacier margin. The 1987 and 1984 volumes were recalculated based on the 1985 curve (Table 1). (b) Volume/peak discharge relationships for floods that route through englacial/subglacial tunnels and those that are triggered by dam failures. The grey ellipse is defined by the error of our calculations, particularly those of peak discharge in which we employ several different methods. Figure 4b is adapted from Walder and Costa (1996) and Costa and Schuster (1988).

Lake elevation was not measured immediately before the 2008 draining. We therefore calculated a lake water recharge in order to estimate lake elevation and volume immediately before the August 2008 jökulhlaup. A seasonal mean refill rate of $0.6-1.0 \mathrm{~m}^{3} \mathrm{~s}^{-1}$ is based on discharge measurements of two major proglacial streams between 15 July and 3 August 2008, made by K. Bazeley (personal communication, 2008). A second approach, using our bathymetric model of the icedammed lake basin (Fig. 3d) and a measured lake surface rise from 2 to 4 August 2008 of $0.32 \pm 0.2 \mathrm{~m}$ (from $423.71 \mathrm{~m}$ ) produces a mean refill rate of $1.29 \mathrm{~m}^{3} \mathrm{~s}^{-1}$. We consider this latter recharge rate to be consistent with the proglacial stream discharge since it includes additional meltwater contributions from subglacial melting and ice calving. Photographic evidence from 2 and 17 September 2007 and 22 October 2008 indicates that the post-draining lake surface level was similar for each draining and that subsequent to each draining, refill to the lake basin during the remainder of each respective melt season was negligible.

Ice-dammed lake volume calculated from our new lake bathymetric data (Fig. 3c and d) enabled recalculation of ice-dammed lake volumes for the 1984 and 1987 jökulhlaups, as reported by Sugden and others (1985) and Russell (1989), respectively. Sugden and others' (1985) volume estimate of $22.3 \times 10^{6} \mathrm{~m}^{3}$ for the 1984 draining has been recalculated as $(25.2 \pm 0.5) \times 10^{6} \mathrm{~m}^{3}$, while Russell's 1989) estimate of $32-36 \times 10^{6} \mathrm{~m}^{3}$ was recalculated as $(31.3 \pm 0.6) \times 10^{6} \mathrm{~m}^{3}$ (Table 1$)$.

\section{Jökulhlaup peak discharge: 1984-2008}

The Clague-Mathews (1973) relationship provides peak discharge values of $652,753,875$ and $416 \mathrm{~m}^{3} \mathrm{~s}^{-1}$ for the 1984, 1987, 2007 and 2008 jökulhlaups, respectively (Table 1). Peak discharges calculated using slope/area

Table 1. Lake level measurements and calculations used to produce jökulhlaup volumes. Error associated with all measurements is $\pm 0.2 \mathrm{~m}$ vertically and $0.1 \mathrm{~m}$ horizontally

\begin{tabular}{|c|c|c|c|c|c|c|c|}
\hline $\begin{array}{l}\text { Jökulhlaup } \\
\text { year }\end{array}$ & $\begin{array}{l}\text { Lake } \\
\text { basin }\end{array}$ & $\begin{array}{c}\text { Pre-drainage } \\
\text { lake level } \\
\text { m }\end{array}$ & $\begin{array}{c}\text { Post-drainage } \\
\text { lake level } \\
\text { m }\end{array}$ & $\begin{array}{c}\text { Lake level surface } \\
\text { level change } \\
\text { m }\end{array}$ & $\begin{array}{l}\text { Volume } \\
\text { change } \\
10^{6} \mathrm{~m}^{3}\end{array}$ & $\begin{array}{c}\text { Peak discharge } \\
\text { (Clague-Mathews) } \\
\mathrm{m}^{3} \mathrm{~s}^{-1}\end{array}$ & $\begin{array}{c}\text { Peak discharge } \\
\text { (Walder and Costa) } \\
\mathrm{m}^{3} \mathrm{~s}^{-1}\end{array}$ \\
\hline 2008 & IDL & $428.3^{*}$ & 404.9 & -23.4 & $12.9 \pm 0.3$ & 416 & 249 \\
\hline 2007 & & 453.7 & 404.5 & -49.2 & $39.1 \pm 0.8$ & 875 & 517 \\
\hline 1987 & & $450.8^{\dagger}$ & $402.5^{\dagger}$ & -48.3 & 31.3 & 753 & 446 \\
\hline 1984 & & $446.7^{\dagger}$ & $406.9^{\dagger}$ & -39.8 & 25.2 & 652 & 387 \\
\hline 2007 & OL1 & 388.1 & 394.9 & +6.8 & 0.84 & - & - \\
\hline 1987 & & - & - & +6.5 & 0.81 & - & - \\
\hline 1984 & & - & - & - & - & - & - \\
\hline 2007 & OL2 & 359.9 & 363.9 & +3.9 & 0.79 & - & - \\
\hline 1987 & & - & - & +3.44 & 0.70 & - & - \\
\hline 1984 & & - & - & +3.11 & 0.63 & - & - \\
\hline
\end{tabular}

*Value derived from a dGPS measurement on 2 August 2008 and a recharge rate based on measurement of lake surface elevation rise between 2 and 4 August $\left(1.29 \mathrm{~m}^{3} \mathrm{~s}^{-1}\right)$.

'Water surface elevations for 1984 and 1987 were measured relative to an arbitrary datum (Sugden and others, 1985; Russell, 1989), but are presented relative to the spillway controlled maximum lake level. 
Table 2. Input data for jökulhlaup peak discharge reconstruction using four variations of the slope/area technique

\begin{tabular}{lcccc}
\hline & $\begin{array}{c}\text { Spillway } \\
\text { cross } \\
\text { section 1 }\end{array}$ & $\begin{array}{c}\text { Spillway } \\
\text { cross } \\
\text { section 2 }\end{array}$ & $\begin{array}{c}\text { Gauged } \\
\text { reach } \\
1987\end{array}$ & $\begin{array}{c}\text { Gauged } \\
\text { reach } \\
2007\end{array}$ \\
\hline Cross-sectional area $\left(\mathrm{m}^{2}\right)$ & 311 & 382 & 174 & 224 \\
Hydraulic radius $(\mathrm{m})$ & 1.7 & 1.4 & 3 & 3 \\
Slope $\left(\mathrm{mm}^{-1}\right)$ & 0.200 & 0.037 & 0.018 & 0.018 \\
Width $\left(\mathrm{m}^{2}\right)$ & 91 & 132 & 56 & 57 \\
Average depth $(\mathrm{m})$ & 5.0 & 5.0 & 3.5 & 4.5 \\
Grain size, $D_{84}(\mathrm{~m})$ min. & 2.0 & 2.0 & 0.2 & 0.2 \\
Grain size, $D_{84}(\mathrm{~m})$ max. & 3.0 & 3.0 & 0.5 & 0.5 \\
Grain size, $D_{90}(\mathrm{~m})$ & 3.0 & 3.0 & 1.0 & 0.5 \\
\% reduction in cross- & 25 & 25 & 5 & 5 \\
sectional area due to & & & & \\
roughness & & & & \\
\hline
\end{tabular}

techniques (Table 2) provide consistently higher estimates of peak discharge. The spillway equation used at the outlet of OL1 (Fig. 1) yielded peak discharges of 2030 and $2774 \mathrm{~m}^{3} \mathrm{~s}^{-1}$ for the 1987 and 2007 jökulhlaups, respectively (Table 3). The spillway-derived peak 2007 jökulhlaup discharge agrees well with the average peak discharge calculated from the results of four slope/area techniques, for the same reach, which ranged from 1887 to $2806 \mathrm{~m}^{3} \mathrm{~s}^{-1}$ (Table 3). Using the same slope/area techniques, peak discharge at the gauged reach was $1647 \mathrm{~m}^{3} \mathrm{~s}^{-1}$ (Table 3). The dramatic attenuation of peak discharge between OL1 spillway and the gauged reach, of $\sim 40 \%$ over just $\sim 5 \mathrm{~km}$, is attributed to temporary storage within the OL2 basin (Fig. 1).

\section{Observations of the ice dam and tunnel entrance}

High-spatial-resolution digital orthophotographs taken in 1985 and 2006 illustrate that the position of the tunnel entrance remained fixed, despite changes in the ice-margin position and elevation (Fig. 3a and b). Comparison of these aerial photographs shows net glacier advance of 90-140 m at the tunnel location.

\section{DISCUSSION}

We have presented a detailed record of draining of the Russell Glacier ice-dammed lake since 1984 and this constitutes one of the longest records of ice-dammed lake drainage in Greenland. We have documented considerable variation in: (1) the levels to and from which the ice-dammed lake drains; (2) the ice-dammed lake volume; (3) the draining frequency; and (4) the peak discharge with distance downstream.

\section{Controls on jökulhlaup magnitude}

Jökulhlaup peak discharge is controlled by the volume of ice-dammed lake water released and lake drainage mechanisms (Tweed and Russell, 1999; Roberts, 2005). In recognition of the first of these controls, Walder and Costa's (1996) modification of the Clague-Mathews relationship was used to predict peak jökulhlaup discharge from the volume of water drained from the ice-dammed lake basin. We found that Walder and Costa's relationship systematically underpredicts jökulhlaup peak discharge at Russell Glacier, and that the volume to peak discharge relationship for the ice-dammed lake lies between the regression lines for ice tunnel and dam-failure datasets (Fig. 4b). This is because jökulhlaups within the empirical dataset used to define Walder and Costa's relationship exhibit a more sedate rising stage, which is in line with predicted exponential tunnel expansion as represented by Nye-Clarke equations (Roberts, 2005). The rising stage of the 1987 Russell Glacier jökulhlaup hydrograph is clearly linear (Russell, 1989, 1993b), which reflects more rapid water release and higher peak discharge than predicted by Walder and Costa's revision of the Clague-Mathews equation. Furthermore, jökulhlaups with a linear rise to peak discharge are subject to a greater degree of downstream discharge attenuation than those with an exponential hydrograph shape (Roberts, 2005). For these reasons, we argue that Russell Glacier jökulhlaups are best characterized by a hydrograph with a linear rise to peak discharge.

The unusually short englacial/subglacial tunnel length $(\sim 1 \mathrm{~km})$ is an important factor in explaining higher-thanpredicted jökulhlaup peak discharges (Walder and Costa, 1996). If the ice-dammed lake drained subglacially for $8 \mathrm{~km}$ to the Russell Glacier snout, a lower peak discharge would result due to lower conduit enlargement rates. A relatively thin ice dam would also be more prone to flotation, allowing water to exit the lake more rapidly. In 2007 and 2008 the ice-dammed lake drained to a level of $404.9 \mathrm{~m}$, which is $\sim 10 \mathrm{~m}$ above the conduit outlet where the jökulhlaups entered OL1. This suggests the presence of a bedrock lip which controls minimum lake level. Observations of jökulhlaup inlet tunnels that remain in the same place during successive draining events imply that bedrock topography controls both conduit location and form at this location. Jökulhlaup flow through an incised bedrockwalled 'Nye channel' will also favour a quicker rise to peak

Table 3. Reconstructed jökulhlaup peak discharge $\left(\mathrm{m}^{3} \mathrm{~s}^{-1}\right)$ for each of the slope/area variants and the weir crest equation

\begin{tabular}{|c|c|c|c|c|c|c|}
\hline & $\begin{array}{c}\text { Spillway crest } \\
(1987)\end{array}$ & $\begin{array}{c}\text { Spillway crest } \\
(2007)\end{array}$ & $\begin{array}{l}\text { Spillway cross } \\
\text { section } 1 \text { (2007) }\end{array}$ & $\begin{array}{c}\text { Spillway cross } \\
\text { section } 2 \text { (2007) }\end{array}$ & $\begin{array}{c}\text { Gauged reach } \\
(1987)\end{array}$ & $\begin{array}{c}\text { Gauged reach } \\
(2007)\end{array}$ \\
\hline Darcy-Weisbach & - & - & 4070 & 3285 & 1207 & 1747 \\
\hline Manning-Limerinos & - & - & 2113 & 1127 & 1063 & 1625 \\
\hline Manning-Strickler & - & - & 3845 & 2051 & 1347 & 2011 \\
\hline Jarrett & - & - & 1195 & 1085 & 778 & 1204 \\
\hline Weir crest equation & 2030 & 2774 & - & - & - & - \\
\hline Average & 2030 & 2774 & 2806 & 1887 & 1099 & 1647 \\
\hline 1987 gauged & - & - & - & - & 1080 & - \\
\hline
\end{tabular}


discharge due to the concentration of hydromechanical erosion processes allowing the rapid evacuation of ice from the bedrock channel (Roberts, 2005).

Jökulhlaup hydrographs are known to attenuate with distance from source because of hydraulic resistance exerted by the proglacial routeways (e.g. Carrivick 2007a,b) and therefore complex proglacial topography, such as the interlinked bedrock basins typical of West Greenland, causes a dramatic attenuation of peak discharge downstream (Sugden and others, 1985). This may partially explain why our slope/area and spillway crest calculations of jökulhlaup peak discharge are so much larger than the peak discharge estimates given by Mernild and others (2008) and Mernild and Hasholt (2009), who utilize stage records $\sim 35 \mathrm{~km}$ downstream, at Kangerlussuaq. Our calculations of peak discharge for the 1987 jökulhlaup display a similar rate of downstream attenuation from the ice-dammed lake, to OL1 and OL2. The gross underestimation of 2007 and 2008 jökulhlaup volumes by Mernild and others (2008) and Mernild and Hasholt (2009) highlights the perils of extrapolating stage/discharge relationships to include higher stage events and the importance of calculating jökulhlaup volume using knowledge of the ice-dammed lake basin.

\section{Jökulhlaup timing and frequency}

Russell and de Jong (1988) and Russell (1989) suggested that the Russell Glacier ice-dammed lake should drain late in the melt season when subglacial/englacial water pressures are more likely to be lower. Thus ingress of lake water to the glacier plumbing system will be facilitated. As the melt season at Russell Glacier typically begins in May, the known draining dates (18 July 1987, 19 August 1984, 31 August 2007 and August 2008) for the Russell Glacier ice-dammed lake (Sugden and others, 1985; Russell, 1989; Mernild and Hasholt, 2009) lend some support to this argument. Icedammed lake drainings can be triggered by sudden reductions in subglacial water pressure resulting from reduced meltwater production (Tweed and Russell, 1999). Interestingly, Mernild and Hasholt (2009) noted that the 2007 and 2008 jökulhlaups occurred 4 days after a decrease in mean air temperature.

Precipitation observed by the lead author of this paper at Russell Glacier during the 1987 jökulhlaup was not considered sufficient to offset the decrease in ablation resulting from the reduction in incoming solar radiation (Russell and de Jong, 1988; Russell, 1989). Similarly precipitation recorded by Mernild and Hasholt (2009) in Kangerlussuaq before the 2007 jökulhlaup is not thought to be significant to triggering of the ice-dammed lake drainage. Van de Wal and Russell (1994) identified a non-convective rainfall event in the 1991 discharge hydrograph record from Russell Glacier; however, ablation-controlled discharge variations provide the greatest overall impact on the meltwater runoff rate. Although reduced subglacial/ englacial meltwater pressure conditions may provide more favourable conditions for lake drainage, the specific timing or triggering threshold for a jökulhlaup during the melt season is likely to reflect the year-to-year variations in melt volume seasonal evolution of the subglacial drainage system (Tedesco, 2007; Mernild and Hasholt, 2009).

Draining of the Russell Glacier ice-dammed lake between the 1950s and 1987 is considered to have occurred every 2-3 years, based on evidence from aerial photographs, sedimentary data and lake refill time (Gordon,
1986; Russell, 1989, 1993a). Mernild and Hasholt (2009) suggest that the ice-dammed lake drained in consecutive years in 1983 and 1984, thereby mirroring the 2007 and 2008 events. Although Sugden and others (1985) suggest that the ice-dammed lake may drain annually, their argument for a jökulhlaup in 1983 was based on wash limit evidence of a jökulhlaup of equivalent or greater magnitude to their observed 1984 flood. The 1984 jökulhlaup had a volume of $(25.2 \pm 0.5) \times 10^{6} \mathrm{~m}^{3}$, which is twice the volume of the 2008 jökulhlaup, thus making it highly unlikely that the lake drained in 1983 . We therefore consider the 2007 and 2008 jökulhlaups to be the first recorded consecutive annual draining events from the Russell Glacier ice-dammed lake.

The 2007 jökulhlaup was the largest ever recorded from this ice-dammed lake. The 2008 jökulhlaup was one-third the volume drained in 2007. To explain the occurrence of two such different jökulhlaups from the same ice-dammed lake in close succession, we invoke different draining and triggering mechanisms. We suggest that the subglacial passage of the 2007 jökulhlaup weakened the ice dam sufficiently to allow the 2008 draining to occur at a much lower lake level. It is possible that much of the subglacial conduit remained open between the two events. It is also possible that the lake did not re-seal after the 2007 draining. A substantial accumulation of naled (aufeis) ice was observed in May 2008, directly in front of the 2007 jökulhlaup conduit outlet, indicating a steady feed of water from the conduit through the winter months. Discharge of water observed from the tunnel outlet in late May 2008 may also have been from leakage of the ice-dammed lake. Observations of the 2007 jökulhlaup tunnel inlets in late May 2008 show that they were covered by ice cliff collapse breccia. Similarly, the 2008 tunnel inlets were observed to collapse within 2 months of the ice-dammed lake draining. It is feasible that rising ice-dammed lake levels during the 2008 melt season enabled the flotation of ice cliff collapse debris from the conduit entrances, permitting the lake to drain.

The Russell Glacier ice-dammed lake clearly experiences two different modes of draining associated with different draining mechanisms, frequencies and flood magnitudes. The fact that the ice-dammed lake did not drain in 2009 suggests that the lake is sealed and that the next jökulhlaup will occur when the lake has filled sufficiently to exert sufficient hydraulic pressure to allow connection with the subglacial drainage system.

\section{Ice-dammed lake/glacier interactions}

Although observations of ice-dynamic responses to lake draining have been made (Sugden and others, 1985; Walder and others, 2006; Mayer and others, 2008), detailed consideration of lake volume, lake levels and ice-margin position for multiple jökulhlaups from the same system is much rarer (Guðmundsson and others, 1995; Roberts and others, 2005; Ng and Liu, 2009). We have demonstrated that following the 2007 draining, glacier advance into the Russell Glacier ice-dammed lake basin reduced the lake basin volume. Our data are compatible with observations of Sugden and others (1985) for the same ice-dammed lake. They reported glacier margin advance following the 1984 jökulhlaup. Jökulhlaup volume and peak discharge therefore decreased. Such feedbacks between ice-dammed lakes and ice-margin position will produce progressive decreases in jökulhlaup magnitude within a jökulhlaup cycle. 


\section{Controls on the jökulhlaup cycle at Russell Glacier}

The fact that the 2007 jökulhlaup is the largest documented from this site is consistent with the onset of a new cycle of draining, as envisaged by Evans and Clague (1994). However, we present field data from a more stable icedammed lake configuration than that described by Evans and Clague, whose model concentrates on a piedmont setting where glacier margin position, lake extent and lake volume fluctuate relatively quickly over time during glacier advance and retreat. At Russell Glacier the first jökulhlaup cycle stopped in 1987 even though the lake was still full. Ice-dammed lake drainage at Russell Glacier is dependent not only upon ice-margin advance and retreat, but also upon the responses of ice thickness and glacier hydrology to subtle changes in glacier mass balance. This serves to emphasize two points. Firstly, this is a modern-day example of cyclical ice-dammed lake drainage events seen during the Little Ice Age, for example in Iceland (Thórarinsson, 1939). Secondly, the occurrence of cycles of jökulhlaups from icedammed lakes can be generated by climate change.

\section{CONCLUSIONS AND WIDER IMPLICATIONS}

Ice-dammed lake drainage at Russell Glacier has renewed after 20 years of dormancy, between 1987 and 2007. We find that ice-margin advance/thickening and retreat/thinning are key factors controlling the occurrence and character of jökulhlaups at this site. Specifically, at Russell Glacier there was a period of ice-margin advance from 1987 to $\sim 1999$ followed by recession $(\sim 50 \mathrm{~m})$ and ice surface lowering ( $\sim 10 \mathrm{~m})$, i.e. ice thinning. Draining of the same lake in 2008 suggests that the 2007 jökulhlaup was the first in a new cycle of ice-dammed lake drainage (Evans and Clague, 1994; Clague and Evans 1997). The 2007 jökulhlaup is the largest documented at this site, and this fact is consistent with the model of Evans and Clague (1994). We find that reduced lake volumes, and thus lower jökulhlaup peak discharges, can be produced by localized ice-margin advance and/or glacier thinning. Our calculations of lake volume drained and peak discharge argue for a non-exponential model for the drainage of the ice-dammed lake, and thus a mechanism that is determined by a relatively thin ice dam, a short bedrockcontrolled subglacial tunnel and hydromechanical erosion of glacier ice. We reconstruct a $40 \%$ attenuation in peak discharge over just $\sim 5 \mathrm{~km}$ due to temporary flood water storage within a series of bedrock-controlled proglacial lake basins. Correct identification of the volume of an icedammed lake is crucial for providing accurate estimates of the total volume of meltwater runoff, which goes into temporary storage at the ice-sheet margin. Using Mernild and Hasholt's (2009) discharge values, drainage of the relatively small ice-dammed lake at Russell Glacier contributes $2-3 \%$ of the annual runoff from the entire Kangerlussuaq basin. It is clear that large ice-dammed lakes, which are numerous in West Greenland, may prevent the direct delivery of significant volumes of meltwater to the oceans over annual to decadal timescales.

\section{ACKNOWLEDGEMENTS}

We thank K. Petersen for logistic support. J.L.C. received financial support from the School of Geography academic development fund. We also acknowledge support from the US National Science Foundation through grant
ARC-0612533. We thank M. Roberts and J. Clague for constructive reviews of the manuscript, and M.T. Guðmundsson for editorial review and advice.

\section{REFERENCES}

Anderson, S.P. and 6 others. 2003. Integrated hydrologic and hydrochemical observations of Hidden Creek Lake jökulhlaups, Kennicott Glacier, Alaska. J. Geophys. Res., 108(F1), 6003. (10.1029/2002JF000004.)

Carrivick, J.L. 2007a. Hydrodynamics and geomorphic work of jökulhlaups (glacial outburst floods) from Kverkfjöll volcano, Iceland. Hydrol. Process., 21(6), 725-740.

Carrivick, J.L. 2007b. Modelling coupled hydraulics and sediment transport of a high-magnitude flood and associated landscape change. Ann. Glaciol., 45, 143-154.

Carrivick, J.L. and E.L. Rushmer. 2009. Proglacial geomorphology and sediment assemblages at Franz Josef Glacier and Fox Glacier, South Westland, New Zealand. Arct. Antarct. Alp. Res., 41(1), 18-36.

Carrivick, J.L., A.J. Russell, F.S. Tweed and D. Twigg. 2004. Palaeohydrology and sedimentology of jökulhlaups from Kverkfjöll, Iceland. Sediment. Geol., 172(1-2), 19-40.

Česnulevičius, A., V. Šeirienė, V. Kazakauskas, V. Baltrūnas, P. Šinkūnas and B. Karmaza. 2009. Morphology and sediments of ice-dammed lake after its outburst, West Greenland. Geologija, 51(1), 42-52.

Chow, V.T. 1959. Open-channel hydraulics. New York, McGrawHill.

Church, M., J. Wolcott and J. Maizels. 1990. Palaeovelocity: a parsimonious proposal. Earth Surf. Process. Landf., 15(5), 475-480.

Clague, J.J. 1997. The 1994 jökulhlaup at Farrow Creek, British Columbia, Canada. Geomorphology, 19(1-2), 77-87.

Clague, J.J. and W.H. Mathews. 1973. The magnitude of jökulhlaups. J. Glaciol., 12(66), 501-504.

Clement, P. 1984. The drainage of a marginal ice-dammed lake at Nordbogletscher, Johan Dahl Land, south Greenland. Arct. Alp. Res., 16(2), 209-216.

Costa, J.E. and R.L. Schuster. 1988. The formation and failure of natural dams. Geol. Soc. Am. Bull., 100(7), 1054-1068.

Dawson, A.G. 1983. Glacier-dammed lake investigations in the Hullet Lake area, south Greenland. Medd. Grønl. Geosci. 11.

Desloges, J.R., D.P. Jones and K.E. Ricker. 1989. Estimates of peak discharge from the drainage of ice-dammed Ape Lake, British Columbia, Canada. J. Glaciol., 35(121), 349-354.

Evans, S.G. and J.J. Clague. 1994. Recent climatic change and catastrophic geomorphic processes in mountain environments. Geomorphology, 10(1-4), 107-128.

Featherstone, R.E. and C. Nalluri. 1982. Civil engineering hydraulics. London, Granada.

Gordon, J.E. 1986. Correspondence. Glacial lake drainage near Søndre Strømfjord, West Greenland. J. Glaciol., 32(111), 304.

Guðmundsson, M.T., H. Björnsson and F. Pálsson. 1995. Changes in jökulhlaup sizes in Grímsvötn, Vatnajökull, Iceland, 1934-91, deduced from in-situ measurements of subglacial lake volume. J. Glaciol., 41(138), 263-272.

Helk, J.V. 1966. Glacier mapping in Greenland. Can. J. Earth Sci., 3(6), 771-774.

Henderson, F.M. 1966. Open channel flow. London, etc., Macmillan.

Higgins, A.K. 1970. On some ice-dammed lakes in the Frederikshåb district, south-west Greenland. Dan. Geol. Fören. Medd., 19(4), 378-397.

Huss, M., A. Bauder, M. Werder, M. Funk and R. Hock. 2007. Glacier-dammed lake outburst events of Gornersee, Switzerland. J. Glaciol., 53(181), 189-200.

Jarrett, R.D. 1984. Hydraulics of high gradient streams. J. Hydraul. Eng., 110(11), 1519-1539. 
Knight, P.G., R.I. Waller, C.J. Patterson, A.P. Jones and Z.P. Robinson. 2000. Glacier advance, ice-marginal lakes and the routing of meltwater and sediment: Russell Glacier, Greenland. J. Glaciol., 46(154), 423-426.

Maizels, J.K. 1983. Palaeovelocity and palaeodischarge determination for coarse gravel deposits. In Gregory, K.J., ed. Background to paleohydrology. Chichester, Wiley, 101-139.

Mathews, W.H. and J.J. Clague. 1993. Record of jökulhlaups from Summit Lake, northwestern British Columbia. Can. J. Earth Sci., 30(3), 499-508.

Mayer, C. and T.V. Schuler. 2005. Breaching of an ice dam at Qorlortossup tasia, south Greenland. Ann. Glaciol., 42, 297-302.

Mayer, C., A. Lambrecht, W. Hagg, A. Helm and K. Scharrer. 2008. Post-drainage ice dam response at Lake Merzhacher, Inylchek Glacier, Kyrgyzstan. Geogr. Ann., Ser. A, 90(1), 87-96.

Mernild, S.H. and B. Hasholt. 2009. Observed runoff, jökulhlaups and suspended sediment load from the Greenland ice sheet at Kangerlussuaq, West Greenland, 2007 and 2008. J. Glaciol., 55(193), 855-858.

Mernild, S.H., B. Hasholt, A.C. Tidwell and D.L. Kane. 2008. Jökulhlaup observed at Greenland ice sheet. EOS, 89(35), 321.

$\mathrm{Ng}$, F. and H. Björnsson. 2003. On the Clague-Mathews relation for jökulhlaups. J. Glaciol., 49(165), 161-172.

$\mathrm{Ng}$, F. and S. Liu. 2009. Temporal dynamics of a jökulhlaup system. J. Glaciol., 55(192), 651-665.

$\mathrm{Ng}$, F., S. Liu, B. Mavlyudov and Y. Wang. 2007. Climatic control on the peak discharge of glacier outburst floods. Geophys. Res. Lett., 34(21), L21503. (10.1029/2007GL031426.)

Richards, K.S. 1982. Rivers: form and process in alluvial channels. New York, Methuen \& Co.

Roberts, M.J. 2005. Jökulhlaups: a reassessment of floodwater flow through glaciers. Rev. Geophys., 43(1), RG1002. (10.1029/ 2003RG000147.)

Roberts, M.J., F. Pálsson, M.T. Guðmundsson, H. Björnsson and F.S. Tweed. 2005. Ice-water interactions during floods from Grænalón glacier-dammed lake, Iceland. Ann. Glaciol., 40, 133-138.

Russell, A.J. 1989. A comparison of two recent jökulhlaups from an ice-dammed lake, Søndre Strømfjord, West Greenland. J. Glaciol., 35(120), 157-162.

Russell, A.J. 1990. Correspondence. Extraordinary melt-water runoff near Søndre Strømfjord, West Greenland. J. Glaciol., 36(124), 353.

Russell, A.J. 1993a. The geomorphological and sedimentary effects of jökulhlaups. (PhD thesis, University of Aberdeen.)

Russell, A.J. 1993b. Obstacle marks produced by flow around stranded ice blocks during a glacier outburst flood (jökulhlaup) in West Greenland. Sedimentology, 40(6), 1091-1111.

Russell, A.J. 1993c. Correspondence. Supraglacial lake drainage near Søndre Strømfjord, Greenland. J. Glaciol., 39(132), 431-433.

Russell, A.J. 1994. Subglacial jökulhlaup deposition, Jotunheimen, Norway. Sediment. Geol., 91(1-4), 131-144.

Russell, A.J. 2007. Controls on the sedimentology of an ice-contact jökulhlaup-dominated delta, Kangerlussuaq, west Greenland. Sediment. Geol., 193(1-4), 131-148.

Russell, A.J. 2009. Jökulhlaup (ice-dammed lake outburst flood) impact within a valley-confined sandur subject to backwater conditions, Kangerlussuaq, West Greenland. Sediment. Geol., 215(1-4), 33-49.
Russell, A.J. and C. de Jong. 1988. Lake drainage mechanisms for the ice-dammed Oberer Russellsee, Søndre Strømfjord, West Greenland. Z. Gletscherkd. Glazialgeol., 24(2), 143-147.

Russell, A.J. and P.M. Marren. 1999. Proglacial fluvial sedimentary sequences in Greenland and Iceland: a case study from active proglacial environments subject to jökulhlaups. In Jones, A.P., M.E. Tucker and J.K. Hart, eds. The description and analysis of Quaternary stratigraphic field sections. London, Quaternary Research Association, 171-208.

Russell, A.J., J.F. Aitken and C. de Jong. 1990. Observations on the drainage of an ice-dammed lake in West Greenland. J. Glaciol., 36(122), 72-74.

Russell, A.J., F.G.M. Tatenhove and R.S.W. van de Wal. 1995. Effects of ice-front collapse and flood generation on a proglacial river channel near Kangerlussuaq (Søndre Strømfjord), West Greenland. Hydrol. Process., 9(2), 213-227.

Russell, A.J., Ó. Knudsen, J.K. Maizels and P.M. Marren. 1999. Channel cross-sectional area changes and peak discharge calculations on the Gígjukvísl during the November 1996 jökulhlaup, Skeiðarárjökull, Iceland. Jökull, 47, 45-58.

Russell, A.J., A.R. Gregory, A.R.G. Large, P.J. Fleisher and T.D. Harris. 2007. Tunnel channel formation during the November 1996 jökulhlaup, Skeiðarárjökull, Iceland. Ann. Glaciol., 45, 95-103.

Ryder, J.M. and M. Church. 1986. The Lillooet terraces of Fraser River: a palaeoenvironmental enquiry. Can. J. Earth Sci., 23(6), 869-884.

Scholz, H., B. Schreiner and H. Funk. 1988. Der Einfluss von Gletscherläufen auf die Schmelzwasserablagerungen des Russell-Gletschers bei Søndre Strømfjord (Westgrönland). Z. Gletscherkd. Glazialgeol., 24(1), 55-74.

Sugden, D.E., C.M. Clapperton and P.G. Knight. 1985. A jökulhlaup near Søndre Strømfjord, West Greenland, and some effects on the ice-sheet margin. J. Glaciol., 31(109), 366-368.

Tedesco, M. 2007. A new record in 2007 for melting in Greenland. Eos, 88(39), 383.

Thompson, S.M. and P.L. Campbell. 1979. Hydraulics of a large channel paved with boulders. J. Hydraul. Res., 17(4), 341-354.

Thórarinsson, S. 1939. The ice dammed lakes of Iceland with particular reference to their values as indicators of glacier oscillations. Geogr. Ann., 21(3-4), 216-242.

Tweed, F.S. and A.J. Russell. 1999. Controls on the formation and sudden drainage of glacier-impounded lakes: implications for jökulhlaup characteristics. Progr. Phys. Geogr., 23(1), 79-110.

Van de Wal, R.S.W. and A.J. Russell. 1994. A comparison of energy balance calculations, measured ablation and meltwater runoff near Søndre Strømfjord, West Greenland. Global Planet. Change, 9(1-2), 29-38.

Walder, J.S. and J.E. Costa. 1996. Outburst floods from glacierdammed lakes: the effect of mode of lake drainage on food magnitude. Earth Surf. Process. Landf., 21(8), 701-723.

Walder, J.S. and 6 others. 2006. Local response of a glacier to annual filling and drainage of an ice-marginal lake. J. Glaciol., 52(178), 440-450.

Wiles, G.C., D.J. Barclay, P.E. Calkin and T.V. Lowell. 2008. Century to millennial-scale temperature variations for the last two thousand years indicated from glacial geologic records of Southern Alaska. Global Planet. Change, 60(1-2), $115-125$. 